\title{
Remembering Ki Hang Kim
}

\section{Mike Boyle}

Published online: 5 March 2013

(C) Springer Science+Business Media Dordrecht 2013

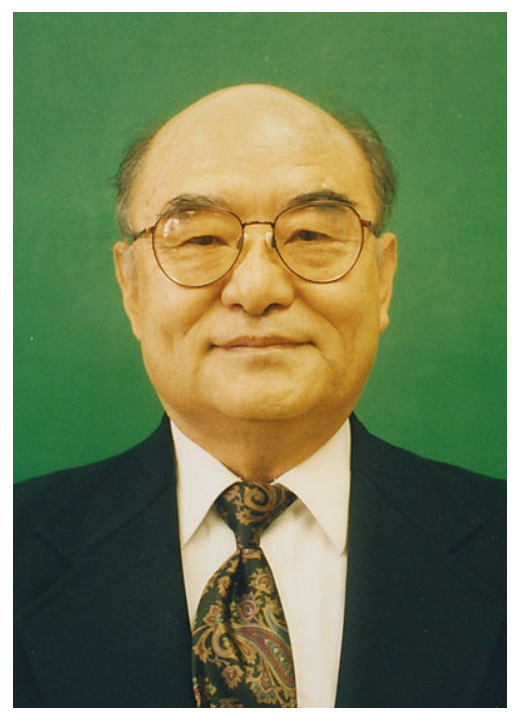

Ki Hang Kim (1936-2009)

This volume is dedicated in memory to Ki Hang Kim, who died in 2009 after several years of declining health.

Hang Kim was born in Anju, North Korea in 1936, the oldest son of a small independent farmer. He grew up within a loving family stressing strict Confucian values and the

M. Boyle (西)

Department of Mathematics, University of Maryland, College Park, MD 20742-4015, USA

e-mail: mmb@math.umd.edu 
importance of education. By age 12, Kim already knew some Chinese, Japanese, English and Russian, and had skipped a couple grades of school.

These were hard times in Korea. Japan ruled Korea 1910-1945. In Kim's childhood, Japan enforced severe instruments of cultural assimilation. For example, Korean could not be studied and Japanese was required in public. The extraction of food and forced labor increased through World War II. In Kim's village, people were hungry. After the war's end, in 1945 the country was divided by the Allied powers. And then came the Korean War (1950-1953).

In the early stages of the war, Kim's region was held for a month or so by the American and South Korean forces. In October 1950, China entered the war, and those forces withdrew. Kim had acted as an informal interpreter for American troops. Several friendly U.S. airmen invited Kim to occupy an empty U.S. Air Force plane seat, and leave with them for the south. At age 14, Kim had six hours to decide. His father urged him to go. Kim took the plane. He would not see his mother and siblings for 30 years, and he would never see his father again.

In South Korea, at Taegu airbase he worked as a laborer and then in food service while studying English in the evening. In March 1952 he passed a qualifying examination and secured the job of interpreter for Colonel Decatur Poindexter Butler of Mississippi, Battalion Commander. As the war's end approached, the Colonel and his family offered to bring Kim to the United States and provide for an education. With difficulty, a passport was secured. In December 1953, Kim sailed under the Golden Gate Bridge. Kim was always grateful to Colonel Butler and his family.

Living and moving with the Butler family, Kim went to high school for two years, first in Georgia and then in Mississippi. In December 1955 Kim enrolled in the U.S. Army. Kim wanted to reduce the financial burden on the Butler family, and the GI bill could finance college. In the Army, Kim served as an interpreter for intelligence units in Korea and Japan. He was selected an outstanding soldier of the year; he received his commendation at the Blue House from President Synghman Rhee of South Korea. After a year in the Army, Kim passed a high school equivalency exam.

Following discharge in December 1957, Kim enrolled at the University of Southern Mississippi. In August 1960, he got his B.S. in Mathematics. A year later, he got his M.S. in Mathematics. Without funds for a Ph.D. program, in September 1961 he started a teaching job at the University of Hartford, in Connecticut. There he met his future wife Myong Ja Kim, born in Seoul. They were married in 1963, and had the first of their two children, John. Kim's Phd ambitions were postponed.

Kim began the PhD program at George Washington University in 1966, at age 30. With a family to support, in 1968 he began also to teach at St. Mary's College in Maryland. The second child, Linda, joined the family. Kim was awarded his PhD from GWU in 1971. He was hired as an associate professor at Pembroke State University of North Carlina in 1971. In 1974, he was appointed a full professor of mathematics and Director of the Mathematics Research Group at Alabama State University (ALASU), where he remained. In 1986 he was appointed Distinguished Professor of Mathematics - the only such appointment in the history of that University.

In the years 1971-1976, writing as Kim Ki Hang Butler, Kim was an author or coauthor of 25 papers, in the general area of semigroups and Boolean matrices. Elsewhere, Putnam Exam winner Fred Roush had finished his 253 page Princeton University $\mathrm{PhD}$ thesis, "Transfer in generalized cohomology theories", in 1972. But following that, before 1976 Roush published only a 5 page paper, in Proceedings AMS 1973. That level of production was going to change. In 1976, by way of Kim's support, Roush joined the ALASU faculty, and began to work with Kim. 
It was a remarkable collaboration.

Before Roush, Kim published as Kim Butler; with Roush, he published as Ki Hang Kim. There are 135 line items of Kim and Roush in the list of Kim's publications. Seven are books. (Kim was also the solo author of the fundamental 1982 reference "Boolean matrix theory and applications", which grew out of his thesis and is still regularly cited.) Their interests were broad: MathSciNet groups their publications in 21 subject areas. They were unafraid of new fields. The final Kim and Roush paper, in 2006, was their only paper in tropical geometry: they proved a result conjectured by Develin, Santos and Sturmfels. They wrote one paper "On a conjecture of Erdős and Renyi”; Erdôs gave an appreciative review. They were tenacious, working on some problems for years. They were prolific. Their work in symbolic dynamics contains elegant insights as well as constructions of brutal complication. They solved some difficult and important problems.

In this volume, focused on symbolic dynamics, we do not try to review all of this work. We review their work in symbolic dynamics, and their work on decidability questions in algebra and number theory.

Biographical reviews of outstanding mathematicians typically contain a record of early honors and a meteoric path to mathematical prominence. Kim's story is notable for the ability and drive by which he emerged from difficult circumstances and went on to great success. 